Helgoländer wiss. Meeresunters. 17, 496-509 (1968)

\title{
Zooplankton, zoobenthos, and bottom sediments as related to pollution and water exchange in the Oslofjord
}

\author{
FREDRIK BEYER \\ Institute of Marine Biology, University of Oslo, Oslo, Norway
}

\begin{abstract}
KURZFASSUNG: Zooplankton, Zoobenthos und Bodensedimente in ihrer Beziehung zur Verunreinigung und zum Wasseraustausch im Oslofjord. Anhand von Untersuchungen, die mit Nansen-Netz, Clarke-Bumpus-Samplers, Schlittenschließnetz und Bodengreifer in den Jahren 1962 bis 1965 im Oslofjord durchgeführt wurden, ergab sich, daß der Artenreichtum der Fauna seewärts eine regelmäßige und stufenweise Zunahme zeigt, die besonders bei den SchlittenSchließnetzfängen sehr ausgedehnt und deutlich zu beobachten war. Unter den planktonischen Tieren sind Aglantha digitale und Ratbkea octopunctata und unter den benthonischen Tieren sind Spioniden und Hesioniden in verunreinigten Gebieten in sehr großer Zahl gefunden worden. Decapode Crustaceen zeigten hinsichtlich ihres Vorkommens eine starke Abhängigkeit von der Zufuhr sauerstoffreichen Wassers. In Gebieten, in denen gar keine Tiere mehr oder nur noch sehr wenige Arten periodisch leben konnten, erwiesen sich die Proben der Bodenablagerungen, die mit einem kleinen Schwerelot gewonnen wurden, dazu geeignet, verschiedene Fäulniszustände durch ihre Farbe zu charakterisieren. Sowohl in der Faunenzusammensetzung als auch im Oxydationszustand des oberen Sediments wurden sehr große Schwankungen während der Untersuchungsperiode beobachtet, die entweder mit Austausch oder Stagnierung des Bodenwassers verbunden waren.
\end{abstract}

\section{INTRODUCTION}

In the papers by M. SARs $(1866,1868)$ and G. O. SARs $(1868,1869)$ on the Oslofjord bottom fauna, a hundred years ago neither pollution, decaying sediments, nor azoic areas were mentioned. At the turn of the century HJORT (in HJORT \& DAHL 1900 ) suggested that the fauna of the inner fjord might be influenced by the reduced concentrations of oxygen, and evidence of this was presented by PETERsen (1915). In his paper on the fauna of the shrimping grounds, Ввосн (1936) discussed the possible influence of sewage discharged into the inner fjord. In RuUD's investigations in 1938 (briefly mentioned in BRAARUD 1945) the amount of organic matter in the sediment and the distribution of decaying and azoic bottom areas were the main subjects of investigation.

From Wiborg's (1940) paper the Oslofjord zooplankton did not seem to be strongly influenced by pollution of the water. In 1951, however, BEYER \& FöYN (1951) found that a great part of the Bunnefjord water masses was completely void of zooplankton because of contamination of the water with $\mathrm{H}_{2} \mathrm{~S}$. 
One might assume that a corresponding change was taking place in the fjord itself. In order to test this assumption, several investigations (STÅLESEN 1963, SCHEMMEKES 1963, STÅLESEN 1964), with trawl, corer, and grab, were arranged in such a way as to facilitate comparison with previous investigations. Another major point in these new investigations was to check possible relations between various fauna components and the qualities of water and sediment. This was the main subject of the benthos investigations conducted by GIESKes (1965) and BEYER \& Versvik (in preparation), and of the zooplankton studies by Beyer, DYBWAd \& Versvik (1967). The present article is based on results reported in the last two papers mentioned and in BEYER's (1967) paper on the sediments.

\section{MATERIAL AND METHODS}

In the reports from which the results presented and discussed here are excerpted the following methods were employed to obtain material.

Zooplankton: About 700 samples were collected on 21 cruises from January, 1962 through September, 1964 by means of divided vertical hauls with Nansen's closing net (NANSEN 1915) and oblique hauls with Clarke-Bumpus plankton samplers (Clarke \& Bumpus 1940). The following stations were occupied (Fig. 1): Elle, Im (maximum sampling depth $90 \mathrm{~m}$ ); Gråöy, Gk (105 m); Spro, F1 (160 m); Steilene, Dk (90 m); Svartskog, Ep (145 m); Bekkelag Basin, Cq (65 m); Oslo Harbour, $\operatorname{Ap}(20 \mathrm{~m})$.

Z oobenthos: By means of Beyer's $50 \mathrm{~cm}$ epibenthic closing net, which is mounted on a toboggan (briefly described in Holme 1964), samples were collected at a number of localities along the fjord. So far, however, only the material obtained at the six innermost localities has been worked up. When the investigations were started in 1962 we knew from trawl and grab samples that the bottom of the Bunnefjord deeps was anoxic and without macroscopic life. For this reason no time was spent on

Table 1

Toboggan net sampling data

\begin{tabular}{|c|c|c|c|c|c|c|}
\hline Locality & Steilene & Gåsöy & $\begin{array}{l}\text { Lysaker- } \\
\text { fjord }\end{array}$ & Helvik & $\begin{array}{c}\text { Kirkevik } \\
\text { Bank }\end{array}$ & $\begin{array}{c}\text { Svart- } \\
\text { skog }\end{array}$ \\
\hline Location & Dk & $\mathrm{Cl}$ & $\mathrm{Bn}$ & $C_{p}$ & Dp & Ep \\
\hline Approximate depth & $100 \mathrm{~m}$ & $70 \mathrm{~m}$ & $75 \mathrm{~m}$ & $85 \mathrm{~m}$ & $85 \mathrm{~m}^{1}$ & $150 \mathrm{~m}$ \\
\hline Number of samples & 27 & 20 & 20 & 11 & 15 & 11 \\
\hline First sample & $\begin{array}{c}\text { January } \\
1962\end{array}$ & $\begin{array}{c}\text { October } \\
1962\end{array}$ & $\begin{array}{c}\text { October } \\
1962\end{array}$ & $\begin{array}{l}\text { March } \\
1963\end{array}$ & $\begin{array}{l}\text { May } \\
1963\end{array}$ & $\begin{array}{l}\text { August } \\
1963\end{array}$ \\
\hline Last sample & $\begin{array}{c}\text { August } \\
1965\end{array}$ & $\begin{array}{c}\text { August } \\
1965\end{array}$ & $\begin{array}{c}\text { August } \\
1965\end{array}$ & $\begin{array}{c}\text { August } \\
1965\end{array}$ & $\begin{array}{l}\text { August } \\
1965\end{array}$ & $\begin{array}{c}\text { August } \\
1965\end{array}$ \\
\hline
\end{tabular}




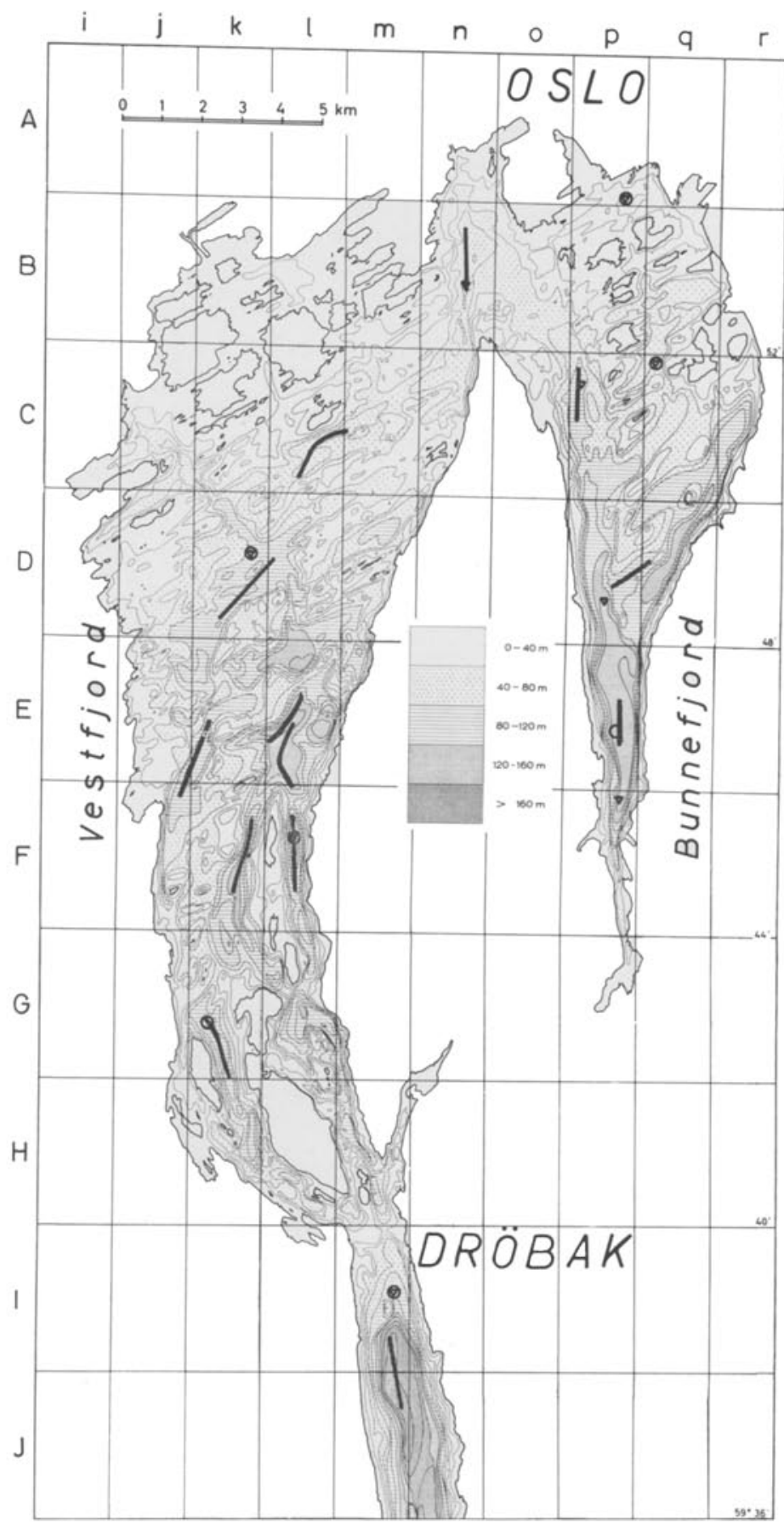

Fig. 1: Bathygraphic chart of the Inner Oslofjord and Dröbak Sound. Tobaggan towing localities are indicated by heavy lines, zooplankton stations by circles. Triangles indicate those routine hydrographical stations which were nearest to the localities chosen for benthos and plankton sampling 
toboggan towing in that area until the substantial improvements appeared after the great deepwater exchange in 1963. For this reason the average figures for the fauna are higher than they should be for the innermost localities. The locations of the towing stations are shown in Figure 1, and further details are given in Table 1. For the sake of comparison, all catches are given as numbers of individuals per $100 \mathrm{~m}^{3}$ of water filtered by the net. It should, however, be emphasized, that for animals which are very closely connected with the substratum the samples are not quantitative. By means of a $0.1 \mathrm{~m}^{2}$ Petersen grab (PETERSEN 1913) 84 samples from the Bunnefjord - Vestfjord area and 25 samples from the Dröbak area were collected.

$\mathrm{S}$ e d i m e $\mathrm{nt}$ : Some 300 sediment cores were taken in the Bunnefjord - Vestfjord area by means of a Moore \& Neill corer (Moore \& Neill 1930) of $18 \mathrm{~mm}$ internal diameter.

Hydrography: Figures based on water bottle samples and standard titrations were placed at our disposal by the Norwegian Institute for Water Research.

\section{RESULTS}

At the most heavily polluted station, Oslo Harbour, exceedingly high concentrations of polychaete larvae, particularly Polydora ciliata JoHNS'ON, were found. Macroplankton was very scarce, but since depth might also be a limiting factor in this shallow area, the Harbour plankton was not included in the comparative distribution studies represented in Figure 2.

It appears from the left part of Figure 2 that pronounced horizontal gradients were found in the distribution of some of the zooplankters. Although reported as an oceanic species by Russell (1953), Aglantha digitale $(A)$ showed a steady increase up the fjord from about 30 individuals per $100 \mathrm{~m}^{3}$ of water outside Dröbak (Im) to about 1600 per $100 \mathrm{~m}^{3}$ in the innermost basin (Cq), which is heavily polluted. Rathkea octopunctata $(B)$ showed a similar trend. Sagitta elegans $(E)$, S. setosa $(F)$, and Calanus finmarchicus finmarchicus $(G)$, on the other hand, were much less abundant in the innermost parts of the fjord.

Although known as a species characteristic of coastal waters and waters with reduced salinity (FrASER 1957), Sagitta setosa was not a permanent resident of the inner Oslofjord, but was occasionally introduced from outside, thus indicating surface water transport up the fjord.

From the Nansen net catches, stage V Calanus (C) and C. f. belgolandicus (D) did not seem to show any preference with respect to locality. Along the bottom, however, as shown in the right part of Figure 2, the total stock of Calanus showed a substantial reduction in average concentration from the Vestfjord ( $\mathrm{Dk}, \mathrm{Cl}, \mathrm{Bn})$ to the Bunnefjord ( $\mathrm{Cp}, \mathrm{Dp}, \mathrm{Ep}$ ). A similar reduction was not found in the stock of Aglantha.

Field observations as well as laboratory experiments during the recent Oslofjord investigations support the generally accepted view, that it is mainly through reducing the concentration of oxygen in the water that domestic sewage has a deleterious effect on the fauna. Unfortunately, $\mathrm{O}_{2}$ concentration of the water actually touching the bottom is not known. Oxygen concentrations recorded a few metres off the bottom 
at Spro (F1) and up the fjord to the Bunnefjord deep (Dp) are shown in Figure 3. Particularly low values of oxygen concentration were found at the beginning and end of 1962. A sweeping exchange occurred in 1963, and low values were again recorded during the end of 1964 . In the fjord outside Dröbak (not shown in Fig. 3) about $7 \mathrm{mg} \mathrm{O} / 1$ were always found near the bottom.

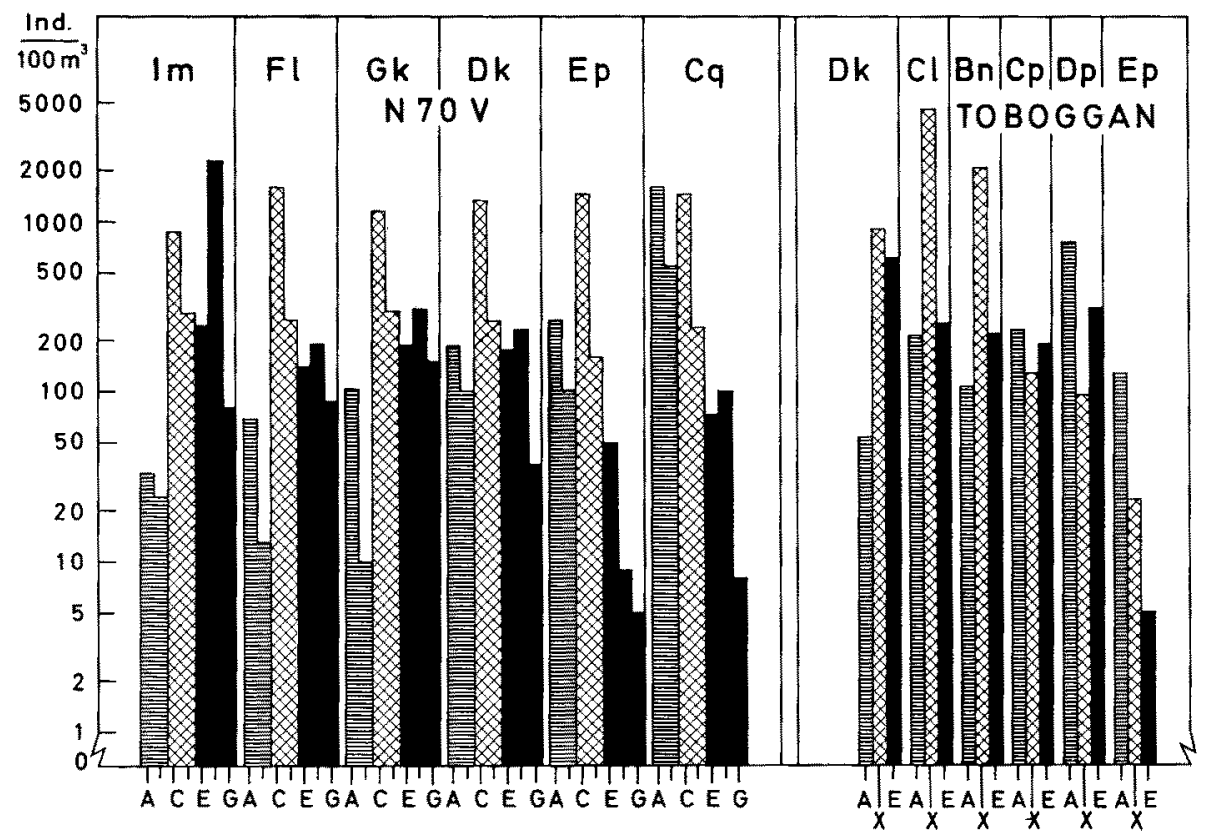

Fig. 2: Average concentrations, given as numbers of individuals per $100 \mathrm{~m}^{3}$ of water, of some selected zooplankters. Im, Fl, etc., indicate the locations of the stations (see also Fig. 1). Lef $t$ : concentrations in the total water column from the vicinity of the bottom to the surface, based on Nansen net (N 70 V) samples. Right: concentrations along the bottom, based on epibenthic closing net (Toboggan) towings. A: Aglantha digitale (O. F. MüLler); B: Rathkea octopunctata (M. SARs); C: Calanus finmarchicus, s. l. stage V; D: C. f. belgolandicus (CLAUs), stage VI; E: Sagitta elegans Verrill; F: S. setosa J. Müller; G: Calanus f. finmarchicus (GUNNERUs), stage VI; X: C. finmarcbicus, s. l.

Regarding the distribution of zoobenthos, sampled by the toboggan net in November 1964, at the outer localities the fauna was both abundant and complex with a biomass predominated by shrimps. Further up the fjord the fauna gradually became less diversified and poorer. At the Kirkevik Bank (Dp), only polychaetes (mainly Spionidae and Hesionidae) were found in addition to some Aglantha. The innermost locality, Svartskog (Ep), was void of bottom animals throughout that year. The leaves found in the samples from the innermost localities demonstrate indirectly the important contribution of the benthos in chewing up and consuming organic material.

During the period of investigation, considerable variations occurred in the fauna caught in the toboggan net at the six innermost localities. The relative difference, however, between the localities, and the relations between the fauna components, 
remained more or less the same. Thus there existed a definite $\mathrm{r}$ anking order of the components according to their occurrence both in space and time.

In Figure 4, the components are arranged in alphabetical order according to decreasing affinity to inner fjord water, or increasing affinity to sea-water. There are only a few minor irregularities in this extremely tidy pattern. One is the occurrence

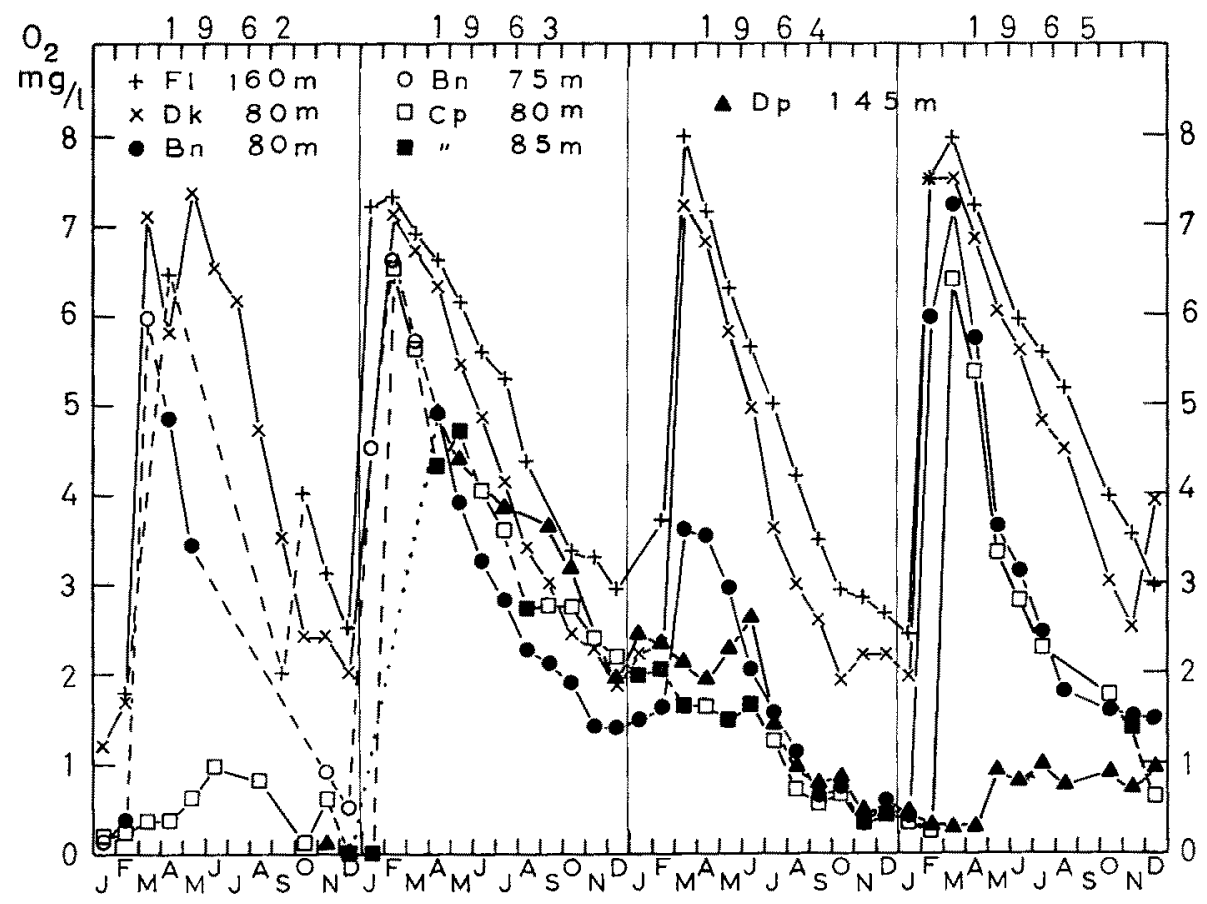

Fig. 3: Concentrations of oxygen $(\mathrm{mg} / \mathrm{l})$ in the deepest water samples at the Vestfjord and Bunnefjord routine stations (see also Fig. 1). Letters underneath give month initials. The data were supplied by the Norwegian Institute for Water Research

of component $k$, Opbiura sp., at the innermost locality. These were a batch of larvae which were about to metamorphose; their settling in that locality proved a complete failure. The other irregularity is the increase in numbers of Spionidae (a) and Hesionidae (b) from Helvik (Cp) to the Kirkevik Bank (Dp). This increase is attributed to special topographical details (cf. Table 1).

With these two exceptions the components may easily be subdivided into three distinct groups.

Group I is made up by Spionidae (a), Hesionidae (b), and Nudibranchia (c); these are indicators of a polluted bottom and reach maximum abundancies at Lysakerfjorden (Bn); their individual numbers decrease towards the sea as well as towards the head; in the first case probably because of increasing competition and predation, in the second case because of partly insufficient oxygen content.

Group II consists of Pboloë minuta (d), Bradyidius armatus (e), and Diaixis 
bibernica $(f)$; these organisms were only scarcely represented in the Bunnefjord ( $\mathrm{Cp}$, Dp, Ep). They did not seem to demand much better conditions, as they showed no further seaward increase in numbers beyond Gåsöy (Cl).

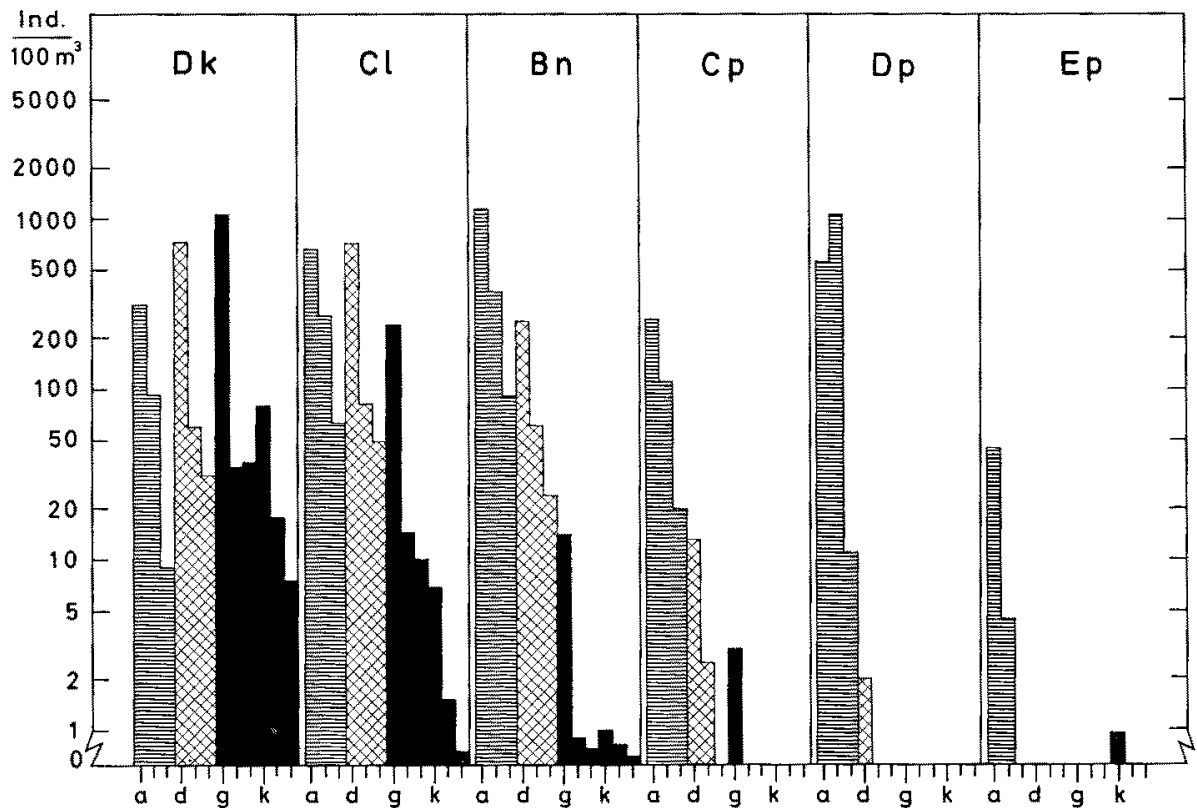

Fig. 4: Average concentrations of benthonic indicator components based on toboggan net samples. Concentrations given as numbers of individuals per $100 \mathrm{~m}^{3}$ of water. $\mathrm{Dk}, \mathrm{Cl}$, etc. indicate the locations of the sampling localities according to Figure 1. The periods of observation are not identical for the various localities, cf. Table 1. $a$ : Spionidae; $b$ : Hesionidae; c: Nudibranchia; d: Pholoë minuta (Fabrrcius); e: Bradyidius armatus (BradY); f: Diaixis bibernica (A. SсотT); g: Tesserogastria musculosa Beyer; h: Cumacea; i: Amphipoda; k: Ophiura sp.; 1: Crangonidae; m: Pandalidae plus Hippolytidae

Group III contains Tesserogastria musculosa (g), Cumacea (b), Amphipoda (i), Ophiura sp. (k), Crangonidae $(l)$, Pandalidae and Hippolytidae $(m)$. All these components show rapidly increasing numbers towards the sea. Even at Steilene (Dk), conditions were insufficient for these organisms during part of the time, particularly during the first months of 1962.

In the absence of bottom fauna, organic matter accumulates and, through the influence of decaying processes, the sediment turns dark. Thus the colour of sediment, and the thickness and location of dark zones in sediment cores (or their absence), makes it possible to distinguish between areas which have recently become anoxic and azoic, or oxic and zoic, and areas which are far, or not so far, from such changes. The coring method represents a means of classifying localities even if animals no longer occur and the toboggan method, therefore, fails. On the other hand, outside regions where anoxic conditions ever occur, sediment cores from various localities look very much alike, in spite of pronounced gradients in the fauna. Thus both methods complement each other, and, combined, they allow a classification of any locality from the 


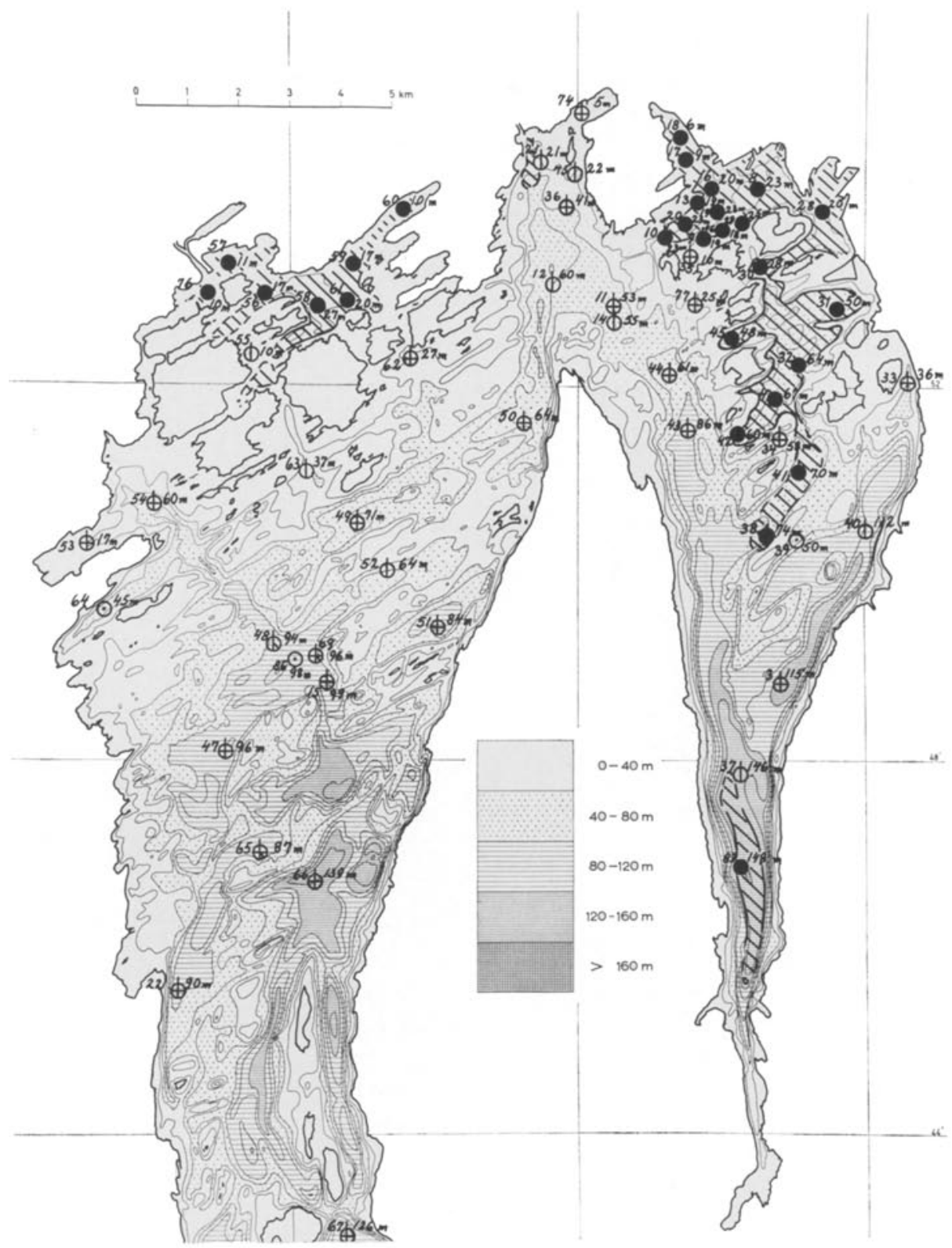

Fig. 5: Distribution of decaying bottom (hatched) and bottom fauna in 1938, based on cores (circles) of $15 \mathrm{~cm}$ diameter (HJort \& RuUD 1938). Numbers: station numbers and depths in $\mathrm{m}$. Open circles: healthy; filled circles: decaying top layer. Vertical (N-S) line through circle: Polychaeta; horizontal (W-E) line: Mollusca; line from centre towards SE: Crustacea; line from centre towards SW: Echinodermata; central dot: fauna not examined 


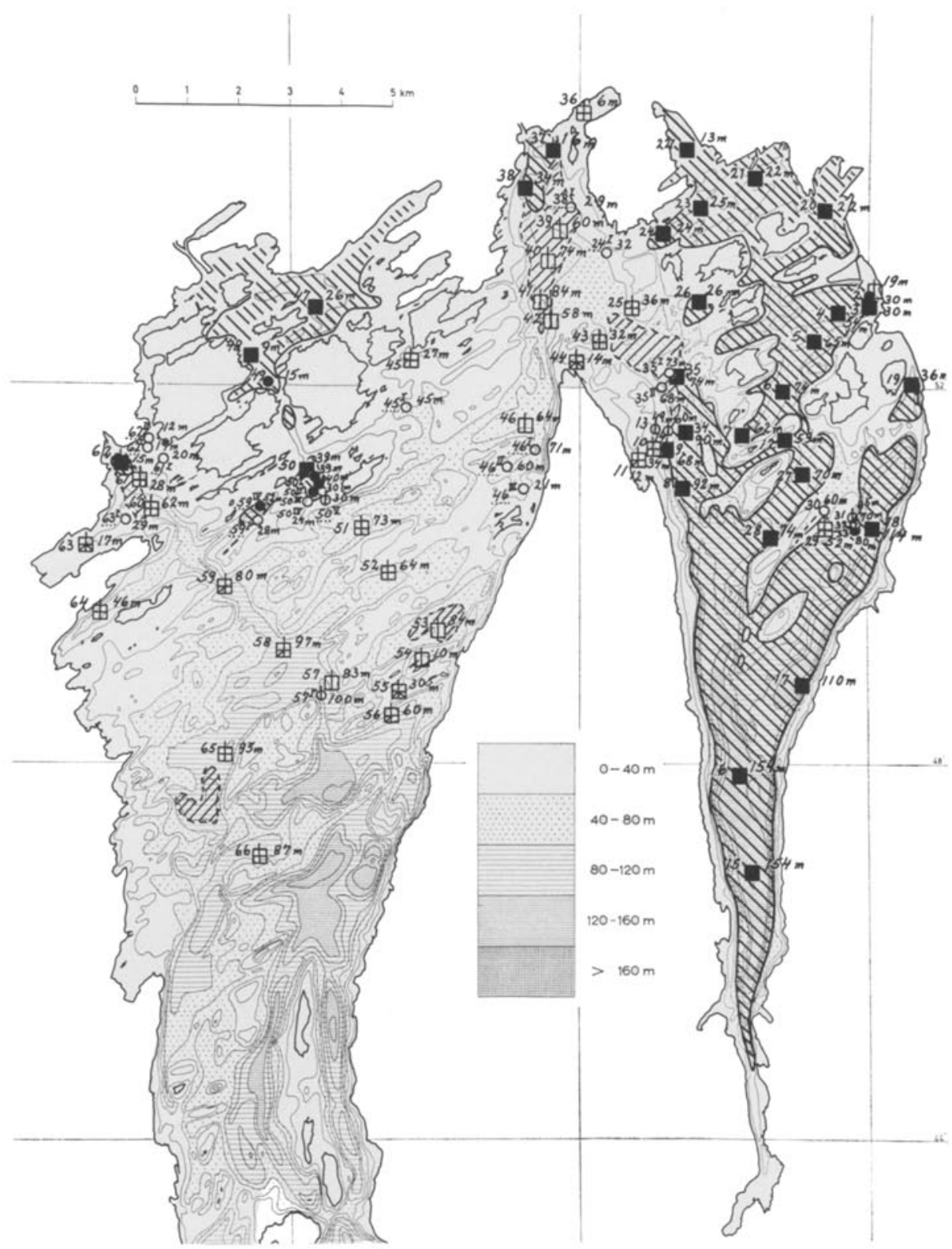

Fig. 6: Distribution of decaying bottom and bottom fauna in 1962 (Data from Schemmeres 1963). NW to SE hatching: decaying areas according to samples taken in October and November; NE to SW hatching: probable extensions of decaying areas in January. Numbers: station numbers and depths in $\mathrm{m}$. Circles: cores of $18 \mathrm{~mm}$ diameter. Squares: $0.1 \mathrm{~m}^{2}$ Petersen grab samples. Open circles and squares: healthy; filled circles and squares: decaying top layer. Vertical (N-S) line through squares: Polychaeta; horizontal (W-E) line: Mollusca; line from centre towards SE: Crustacea; line from centre towards SW: Echinodermata 


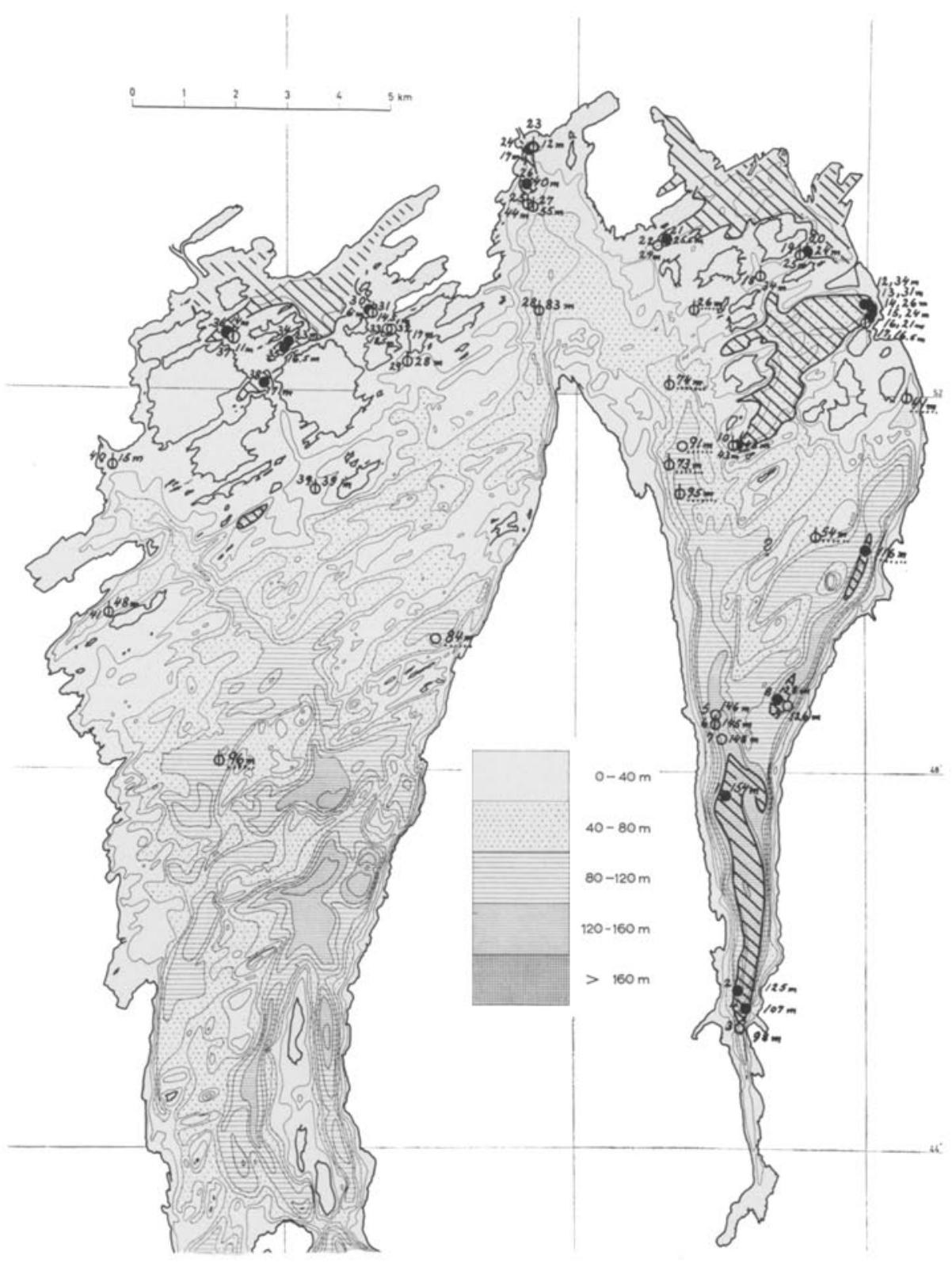

Fig. 7: Distribution of decaying bottom areas (hatched) in August 1965, based on cores (circles) of $18 \mathrm{~mm}$ diameter. Circles without station numbers indicate cores taken in January 1966. The numbers of the stations were the same as those given in Figure 6 in the same positions. Open circles: healthy; filled circles: decaying top layer. Vertical (N-S) line through circle: Polychaeta 
Harbour basin to the fjord outside Dröbak. The scale worked out should become of importance in the evaluation of the future development in the fjord.

The light colour of the sediment found some distance below the sediment surface (from somewhere between $5 \mathrm{~cm}$ and $35 \mathrm{~cm}$ core depth and downwards) in regions now characterized by the anoxicity of the top sediment, indicates a previous occurrence of a satisfactory oxygen balance. According to BigGs (1967), one might assume that the grey sediment was also black when it was nearer the sediment surface, and that the present difference in colour is due to hydrotroilite having altered with time to pyrite. The striking decrease towards the black top layer of sediment in the numbers of Foraminifera (RISDAL 1963) and faecal pellets leaves no doubt, however, that in the Oslofjord the life conditions at the sediment surface have changed with time. Gross (1967) found that black layers of sediment were still present at $20 \mathrm{~m}$ of sediment depth, 4,000 to 5,000 years after sedimentation.

In Figures 5,6 and 7, the distribution of areas with anoxic top sediment layers is indicated by hatching.

Both fauna and sediment studies, as well as fishermen's records, leave no doubt that oxygen deficiency is more extensive, frequent, and severe at the present time than thirty or more years ago. One of the main results of the 1962 to 1966 investigations is the discovery of the immense extent of short-term variations (Figs. 6 and 7).

A distribution of decaying areas almost like that shown in Figure 7 was recorded already in January, 1964; it was the result of the previously mentioned great deepwater exchange in 1963 (Fig. 3).

\section{SUMMARY}

1. Increasing attention has been paid to pollution and oxygen shortage in the Oslofjord. Recently, a number of investigations were carried out (1962 to 1966) in cooperation with the Norwegian Institute for Water Research. The present article summarizes a few of the major results of some of these investigations, which are based on plankton samples (vertical hauls with a Nansen closing net), zoobenthos and hyperbenthos samples (towings along the bottom with Beyer's toboggan), and sediment cores (Moore \& Neill corer).

2. Aglantha digitale and Ratbkea octopunctata were found in greatest numbers in the most heavily polluted areas, where bottom water and sediment were generally anoxic and azoic.

3. Spionidae, Hesionidae, and Nudibranchia thrived in polluted areas when these were not anoxic. The remaining of the benthos components compared occurred primarily in water of better quality. A consistent and distinct ranking order was found for all these components.

4. In areas where no bottom fauna was found, and in transitional zones, black or dark layers in the sediment indicated various degrees of oxygen insufficiency.

5. Combinations of toboggan towings and coring surveys provide a useful basis for classifications.

6. Most remarkable differences (variations) were recorded in the successive years of the survey. 


\section{LITERATURE CITED}

BEYER, F., 1967. Bunnsedimenter og bunnfauna $\mathrm{i}$ indre og midtre Oslofjord i 1938 og 19621966. In: Oslofjorden og dens forurensningsproblemer. 1. Undersøkelsen 1962-1965. Norwegian Institute of Water Research, Oslo, 6, 1-119.

- DybWAD, Å. \& VERsviK, J., 1967. Zooplankton. In: Oslofjorden og dens forurensningsproblemer. 1. Undersakelsen 1962-1965. Norwegian Institute of Water Research, Oslo, $5,1-66$.

- \& FøYr, E., 1951. Surstoffmangel i Oslofjorden. En kritisk situasjon for fjordens dyrebestand. Naturen 75 (10), 289-306.

- \& Versvik, J., 1968. Undersøkelse av virvelløse dyr langs med bunnen av indre Oslofjord i 1962-1965. In: Oslofjorden og dens forurensningsproblemer. 1. Undersøkelsen 1962-1965. Norwegian Institute of Water Research, Oslo, 7 (in prep.).

Biggs, R. B., 1967. The sediments of Chesapeake Bay. In: Estuaries. Ed. by G. H. Lauff. Publs Am. Ass. Advmt. Sci. 83, 239-260.

BraArud, T., 1945. Forurensning og selvrensning av sjøvann. Undersøkelser i Oslofjorden. Naturen $69(7 / 8), 212-235$.

Broch, HJ., 1936. Die Bedeutung der Drobak-Schwelle für die Bodenfauna der GarnelenFelder. Avb. norske VidenskAkad. Oslo (Mat.-Nat. Kl.) 5 (1935), 1-32.

Clarke, G. L. \& Bumpus, D. F., 1940. The plankton sampler - an instrument for quantitative plankton investigations. Spec. Publs limnol. Soc. Am. 5, 1-8.

FRASER, J. H., 1957. Chaetognatha. (1st rev.). Fich. Ident. Zooplancton 1, 1-6.

GrEskEs, W. C., 1965. Some investigations into the hydrographical and biological conditions of the Frognerkilen (Oslofjord). Spec. Rep. Inst. mar. Biol., Oslo 1965, 1-59 (type-wr. copy).

Gross, M. G., 1967. Concentrations of minor elements in diatomaceous sediments of a stagnant fjord. In: Estuaries. Ed. by. G. H. Lauff. Pubsl Am. Ass. Advmt Sci. 83, 273-282.

HJorT, J. \& DAHL, K, 1900. Fishing experiments in Norwegian fiords. Rep. Norw, Fishery mar. Invest. 1 (1), 1-215.

- \& Ruvd, J. T., 1938. A bottom-sampler for the mud-line. Hvalrad. Skr. 17, 145-151.

Holme, N. A., 1964. Methods of sampling the benthos. Adv. mar. Biol. 2, 171-260.

Moore, H. B. \& NenL, R. G., 1930. An instrument for sampling marine muds. J. mar. biol. Ass. U.K. 16 (2) 589-594.

Nansen, F., 1915. Closing-nets for vertical hauls and for horizontal towing. Publs Circonst. Cons. perm.-int. Explor. Mer 67, 3-8.

Petersen, C. G. J., 1913. Havets Bonitering. II. Om Havbundens Dyresamfund og om disses Betydning for den marine Zoogeografi. Beretn. Minist. Landbr. Fisk. dan. biol. Stn 21, $1-42$.

- 1915. Om Havbundens Dyresamfund i Skagerak, Kristianiafjord og de danske Farvande. Beretn. Minist. Landbr. Fisk. dan. biol. Stn 23, 3-26.

Risdal, D., 1963. Foraminiferfaunaen i en del sedimentkjerner fra indre Oslofjord. Norg. geol. Unders. 224, 1-90.

Russell, F. S., 1953. The medusae of the British Isles. University Press, Cambridge. 530 pp. (E. T. Browne Monogr. mar. Biol. Ass. U. K.).

SARS, G. O., 1868. Beretning om en i Sommeren 1865 foretagen zoologisk Reise ved Kysterne af Christianias og Christiansands Stifter. Nyt Mag. Naturvid. 15, 84-128.

- 1869. Undersøgelser over Christianiafjordens Dybvandsfauna, anstillede paa en i Sommeren 1868 foretagen zoologisk Reise. Christiania, $58 \mathrm{pp}$.

SARs, M., 1866. Om arktiske Dyreformer i Christianiafjorden. Forb. VidenskSelsk. Krist. $1865,196-200$.

- 1868. Bidrag til Kundskab om Christianiafjordens Fauna. Nyt Mag. Naturvid. 15, 231-344.

Schemmekes, J. G. S., 1963. Studien über die Chemie und Fauna des Weichbodens in Sauerstoff-freien und Sauerstoff-armen Gebieten des inneren Oslofjordes. Spec. Rep. Inst. mar. Biol, Oslo, 1963, 1-40 (type-wr. copy). 
STÅLESEN, G., 1964. En sammenlikning mellom bunnfaunaen på reke-feltene i Oslofjorden like innenfor og utenfor Drøbakterskelen i 1933/34 og 1962. Hovedfagsoppg. mar. zool., Univ. Oslo, 50 pp. (type-wr. copy).

STÅLESEN, O., 1963. Fisken på rekefeltene i Oslofjorden. En undersøkelse av de forandringer som har funnet sted i de siste 30 ar. Hovedfagsoppg. mar. zool., Univ. Oslo, 43 pp. (typewr. copy).

WiborG, K. F., 1940. The production of zooplankton in the Oslo Fjord in 1933-1934 with special reference to the copepods. Hvalråd. Skr. 21, 1-87.

\section{Discussion following the paper by BEYER}

Postma: Is anything known about the rate of sedimentation in the inner part of the Oslofjord?

BEYER: We do have a rough idea; it is based partly on cores from the Dramsfjord, which is a side branch of the Oslofjord, and partly on old records. In the Dramsfjord, annual layers in the sediment are produced by the conspicuous river flood. Because of the extremely complicated topography of the Oslofjord, with a large number of islands, ridges, and troughs, the sedimentation rate certainly is different in different parts of the fjord. In the open parts of the inner Oslofjord, the rate of sedimentation seems to be of the order of $1 \mathrm{~mm}$ of settled sediment per year.

KORRINGa: In one of your pictures you showed us that leaves of trees are present where the benthic fauna is absent, and you concluded that it is the benthic fauna which destroys the leaves. Is this conclusion warranted? Is the biodegradation of the leaves not caused by microorganisms, and is not the microbial composition different according to the degree of pollution and the oxygen level? Anaerobic breakdown is often a slow process.

BEYER: When the leaves are broken down into small parts by animals, their surface areas become much greater; for this reason presumably, the leaves become more accessible to the bacteria. Our evidence is, however, merely indirect; it is based on the fact that when there is no macrofauna, or even a poor macrofauna and oxygen, we always find leaves, whereas leaves are seldom found in areas with an abundant macrofauna.

PEARSON: With regard to the part played by the deposition of leaves and terrestrial vegetation on the bottom of the fjord, we have some observations from a loch of the West coast of Scotland which may be of some interest. In Loch Linnhe there are certain sampling stations where we have recorded a considerable deposition of leaf material on the bottom. The distribution of this material is very patchy, and the deposition appears to follow a seasonal pattern, building up towards the end of autumn, reaching a maximum in December, and falling off to a relatively low level during the ensuing summer months. The fauna found where such material is abundant is itself very rich, the biomass of the macrobenthic fauna being as much as 5 to 6 times as great as that of surrounding areas which do not have such a large leaf content. It is probable that the deposition of this terrestrial vegetative material on the loch bottom has a considerable influence on the type and richness of the benthic fauna found; this is an important factor in the total ecosystem of this loch, and in lochs of similar fjord-type systems.

BEYER: At the west coast of Norway, off the biological station at Espegrend, there is a locality where dead benthos algae, Laminaria etc., accumulate in great abundance, due to the current pattern; there is also an abundance of fish and of a variety of other animals. But in this open fjord anoxic conditions never occur. Certainly, the settling of leaves will be strongly influenced by the current pattern. As to the correlation between the fauna and the physical environment, we hope to learn more about this when we, in the near future, have placed an automatic camera on the toboggan, so that we can take photographs in front of the sampling gear. 
Rheinhelmer: Ich glaube, daß zum Teil - wie Herr Professor Korringa schon andeutete tatsächlich die veränderte Bakterienpopulation von entscheidender Bedeutung ist. Denn wenn Schwefelwasserstoff entsteht, sterben meisten Bakterien ebenso wie die Protozoen ab, und so können sich nur wenige Anaerobe halten. Dann werden solche Dinge wie Blätter nur noch teilweise abgebaut und können sich sehr lange halten.

BEXER: Yes, thank you, I perfectly agree. 